Article

\title{
Whey proteins characterization, free amino acids profile and antimicrobial study of some dairy drinks based on Milk Serum
}

\author{
Doina Prodan ${ }^{1}$, Miuța Filip ${ }^{1 *}$, Mihaela Vlassa ${ }^{1}$, Marioara Moldovan ${ }^{1}$, Rahela Carpa ${ }^{2}$, Viorica \\ Tarmure ${ }^{3}$, and Andreea Simona Popa ${ }^{3}$
}

1 Raluca Ripan Institute for Research in Chemistry, Babeș-Bolyai University, 30 Fântânele Str., RO-400294 Cluj-Napoca, Romania; doina prodan@yahoo.com (D.P); mihaela cecilia@yahoo.com (M.V.); mmarioara2004@yahoo.com (M.M.);

2 Department of Molecular Biology and Biotechnology, Babeș-Bolyai University , 1 Kogălnice anu M. Street, RO-400084, Cluj-Napoca, Romania; k hella@yahoo.com (R.C);

3 Faculty of Dentistry, Iuliu Ha tie ga nu University of Me dicine and Pharmacy, 31 A. Iancu Street, RO-400083, Cluj-Napoca, Romania; tarmurev@yahoo.com (V.T.); spopandreea@yahoo.com (A.S.P.)

* Correspondence: filip miuta@yahoo.com; filip.miuta@ubbcluj.ro; Phone:+40 264 580165; Fax: +40 264 420441 (M.F.)

\begin{abstract}
:
The aim of this study was characterization of some dairy drinks based on Milk Serum regarding major whey proteins (WP) and free amino acids (FAAs) using reversed phase high performance liquid chromatographic (RP-HPLC) methods. The studied WP, $\alpha$-lactalbumin ( $\alpha$-La), bovine serum albumin (BSA), $\beta$-lactoglobulin A ( $\beta$ - $\mathrm{Lg} A)$ and $\beta$-lactoglobulin B $(\beta$ - $\mathrm{Lg} B)$ were separated on Aeris $\mathrm{XB}-\mathrm{C} 18$ column at $214 \mathrm{~nm}$ detection. The RP-HPLC method was validated by selectivity, linearity (R2 $\geq 0.99$ ), sensitivity (LOQ, 1.35-10.08 $\mu \mathrm{g} \mathrm{mL}^{-1}$ ), accuracy (recovery 96.79-103.07\%) and precision (\% RSD $\leq 4.13 \%$ ). The total studied WP in studied dairy drinks varied between 1.42 and $3.047 \mathrm{~g} \cdot \mathrm{L}^{-1}$. The chromatographic profile of FAAs (aspartic acid, glutamic acid, serine, histidine, arginine, glycine, threonine, alanine, tyrosine, cysteine, tryptophan, methionine, valine, phenylalanine, isoleucine, leucine and lysine) was determined in lyophilized concentrate of Milk Serum by RPHPLC using pre-column derivatization reaction with orthophthalaldehyde(OPA). The total studied FAAs in studied samples varied between 1.103 and $1.119 \mathrm{mg}^{\cdot} \mathrm{g}^{-1}$. Moreover, the Milk Serum show ed bacteriostatic activity against two bacterial strains Escherichia coli and Staphylococcus aureus. The obtained results confirm that dairy drinks based on the Milk Serum constitutes a valuable sources of bioactive components with benefits for human healthy nutrition.
\end{abstract}

Keywords: Milk Serum, whey proteins, RP-HPLC-UV, free amino acids, RP-HPLC-FLD, antimicrobial study

\section{Introduction}

The Milk whey (also called Milk Serum) represents a complex and heterogeneous mixture proteins with wide biological, nutritional and technological applications in the formulation of modern food and beverages. Whey proteins are unique as they contain all the essential amino acids of good quality protein [1]. Bovine milk and colostrum are considered the most important sources of natural bioactive components, like specific proteins, peptides, lipids, and carbohydrates [2]. Amino acids are found in protein-containing foods such as milk and milk products and have vital importance for human life. Eight amino acids are thought to be essential for humans, and they must be absorbed from foods containing animal proteins or a suitable combination of plant proteins, because the human 
body can't synthesize them. Determination of the composition and content of amino acids in milk products is therefore an important measure in ensuring quality and nutrition al value [3].

Considered an abundant dairy by-product, the valorization of whey components is related to the recovery and concentration of whey proteins as new ingredients for food and non-food sectors as well as the improvement of economic revenue for the dairy industry [4,5]. As dietary protein supplement the whey improve muscle strength and body composition, and can prevent cardiovascular disease and osteoporosis [2].

The whey proteins contain the major components $\beta$-lactoglobulin, $\alpha$-lactalbumin, B and immunoglobulin and numerous minor proteins, such as lactoferrin, lactoperoxidase, proteose peptone, osteopontin, lysozyme, among others [6]. The characteristics and composition of milk whey depend on the source of milk (cow, sheep, goat, etc.), the feed of milk-producing animal, the stage of lactation, the processing method used and the time of the year when the milk samples were collected [7].

Nowadays, a variety of methods have been developed to analyses whey proteins: reversedphase high performance liquid chromatography (RP-HPLC) [5,8-10], ultra HPLC tandem mass spectrometry [9,11-15], electrophoretic techniques $[9,16,17]$, immunoaffinity chromatography $([18,19]$, Enzyme Linked Immunosorbent Assay (ELISA) [20] [21] and a novel visualized microarray method [22]. However, HPLC method allows rapid and automated analysis, characterized by good separations, high resolutions and accuracy and reproducible results, especially for simultaneous detection of multiple whey proteins.

There are several methods described in literature for analysis of free amino acids including HPLC that couples diode array and fluorescence detection [23,24], HPLC tandem mass spectrometry [25,26], gas chromatography with mass spectrometry [27], capillary electrophoresis [28] and ion exchange chromatography [29]. To increase the sensitivity of amino acids detection, the amino acids are usually derivatized before analy sis and derivatization reagents, such a s ortho-phthaldialdehyde (OPA) [25,23], 9-fluorenyl-methyl chloroformate (FMOC-Cl) [30], phenylisothiocyanate (PITC) ([31] and 4-dimethylaminoazobenzene-4-sulfonyl (dabsyl)chloride [32] are used for amino acid analysis.

The purpose of the present study was the characterization of whey proteins ( $\alpha$-La, BSA, $\beta$-Lg A and $\beta$ - Lg B) in some dairy drinks based on Milk Serum by developing and validated of a RP-HPLC method. Also, determination of chromatographic profile of seventeen FAAs (aspartic acid, glutamic acid, serine, histidine, arginine, glycine, threonine, alanine, tyrosine, cysteine, tryptophan, methionine, valine, phenylalanine, isoleucine, leucine and lysine) in concentratelyophilized of Milk Serum has been performed. This study provide an important evaluation regarding valuable bioactive components, WP and FAAs, in studied dairy drinks based on Milk Serum.

\section{Materials and Methods}

\subsection{Reagents, standards and samples}

All reagents were of analytical grade. The all standards of whey protein: $\alpha$-(lactoalbumin $(\alpha-\mathrm{La})$, $\beta$-lactoglobulin type $A(\beta$-Lg A), $\beta$-lactoglobulin type B $(\beta$ - $\operatorname{Lg} B)$ and bovine serum albumin (BSA) as well as L- amino acids (aspartic acid, glutamic acid, serine, histidine, arginine, glycine, threonine, alanine, tyrosine, cysteine, tryptophan, methionine, valine, phenylalanine, isoleucine, leucine and, lysine), each of purity $>98 \%$ and orthophthalaldehyde (OPA) reagent were purchased from SigmaAldrich (Darmstadt, Germany):,

Ultrapure water $(<18.3 \mathrm{M} \Omega \cdot \mathrm{cm})$ was prepared with Milli-Q plus; Symplicity ${ }^{\circledR} \mathrm{UV}$ (Millipore, USA) water purification system (Merck KGaA, Darmstadt, Germany). Trifluoroacetic acid (TFA), acetonitrile (ACN), methanol, tetrahydrofuran, sodium hydroxide (pellets) and phosphoric acid (85 $\%)$ were purchased from Merck (Darmstadt, Germany).

The studied dairy drinks based on sweet whey (Milk Serum namelly Zonar) obtained from cow milk by an own technology were produced and distributed by S.C. EmbryOm Capital investment S.R.L., (Satu-Mare, Romania). 
For this experiment we used five types of dairy drinks (ten samples) based on Milk Serum:

Z-n is Milk Serum dairy drink obtained from different milk batches; Z-Gi-Ho is a dairy drink based on Milk Serum with ginger extract and honey; Z-Co-Ho is a dairy drink based on Milk Serum with cocoa extract and honey; Z-Ag is a dairy drink based on Milk Serum with colloidal silver solution; Z-Baby is a dairy drink based on Milk Serum for baby children; For to determination the free amino acids in dairy drink were used concentrate lyophilized of milk serum samples (Z-4, Z-6).

\subsection{HPLC method for WP determination}

The analyses were carried out on a High Performance Liquid Chromatograph with UV/VIS detector (Jasco International Co., LTD., Tokyo, Japan)and $20 \mu \mathrm{L}$ sample loop (Rheodyne, Thermo Fischer Scientific, Waltham, MA, USA) for manual injection of sample. Separations were performed on a reversed-phase analytical column Aeris (WIDEPORE, $3.6 \mu \mathrm{m}, \mathrm{XB}-\mathrm{C} 18,250 \times 4.6 \mathrm{~mm}, 200 \AA$ ) column (Phenomenex); the system was controlled and the experimental data analysed were performed with the ChromPass softw are (version v1.7, Jasco International Co., LTD., Tokyo, Japan). Gradient elution was carried out with a mixture of two solvents. Solvent A consisted of $0.1 \%$ trifluoroacetic acid (TFA) in water and solvent B was $0.1 \%$ TFA in $80 \%$ ACN with the following gradient program: linear gradient from $35 \%$ B to $80 \%$ B for 15 minutes, from $80 \%$ B to $60 \%$ B for 5 minutes, and from $60 \% \mathrm{~B}$ to $35 \%$ B for 5 minutes; Column temperature was kept to $40{ }^{\circ} \mathrm{C}$, the flow rate at $0.7 \mathrm{~mL} \cdot \mathrm{min}^{-1}$ and the detection wavelength was set at $214 \mathrm{~nm}$. The injection volume consisted of $20 \mu \mathrm{L}$.

Standard solution. The stock standard solution of studied whey proteins ( $1 \mathrm{mgmL}^{-1}$ each) of were prepared in water. The stock solution were stored in the dark at $-20^{\circ} \mathrm{C}$ for no more than 1 month. Work standard solutions were prepared from this stock solution and were diluted step by step with the water immediately before use.

Sample preparation. The dairy beverage sample $(2 \mathrm{~mL})$ was diluted with $3 \mathrm{~mL} 0.1 \%$ TFA in $5 \%$ ACN solution and $3 \mathrm{~mL}$ of $70 \%$ ACN solution. The final solution was centrifuged (Eppendorf $5804 \mathrm{R}$ centrifuge, Hamburg, Germany) at $4500 \mathrm{rot} \mathrm{min}^{-1}$ for $20 \mathrm{~min}$ at $20^{\circ} \mathrm{C}$ and finally, the solution was passed through a $0.45 \mu \mathrm{m}$ nylon membrane filter (Teknokroma) and injected in the HPLC system .

HPLC validation method. The RP-HPLC method for the determination of WP dairy beverages was validated for selectivity, linearity, sensitivity (limits of detection (LOD) and limits of quantification (LOQ)), accuracy (recovery) and precision according to ICH guidelines [33].

Selectivity was tested by comparing the chromatogram of a standard solution of whey proteins, with that of a Milk Serum dairy drink.

Linearity of the method was studied by injection of six known concentrations of standard solution of whey protein in the range of 20 to $250 \mu \mathrm{g} \mathrm{mL}^{-1}$. Each standard solution was analyzed in triplicate. Four independent calibration curves w ere plotted by peak area versus concentration of the standard. Linear regression analysis was used to calculate the slope, intercept and correlation coefficient of each curve.

Sensitivity: The limit of detection (LOD) and limit of quantitation (LOQ) were calculated using signal-to-noise ratio of 3:1 and 10:1, respectively.

Precision: The analytical precision from the data of the intra-day (6 replicate analysis of sample at $100 \%$ of test concentration) and inter-day (three replicate for three consecutive days) determinations were performed on the three different concentrations of standard solutions. The precision was expressed as percentage of relative standard deviation (\%RD).

Accuracy: To evaluate the accuracy of the method was study the recovery degree. Standard addition was performed with pre-analyzed standard solution. Three different concentration levels of $50 \mu \mathrm{g} \cdot \mathrm{mL}^{-1}$ (low level), $150 \mu \mathrm{g} \cdot \mathrm{mL}^{-1}$ (intermediate level) and $200 \mu \mathrm{g} \cdot \mathrm{mL}^{-1}$ (high level) of standard mixtures were added to the Milk Serum sample. Spiked samples were prepared in triplicate. The recovery was calculated as follows equation (1).

$$
\text { Recovery }(\%)=\frac{\text { Detected amount-Original amount }}{\text { Spiked amount }} \times 100
$$




\subsection{HPLC method for FAAs determination}

The FAAs analysis were performed on a HPLC Agilent 1200 series chromatograph (Agilent Technologies, Morge, Switzerland), equipped with autosampler (ALS G 1329 A), degasser (G 1322 A), quaternary pump (G 1311 A), thermostat (TCC SL G 1316 B) and fluorescence detector FLD (G 1321A). ChemStation software (version B.04.01, Waldbronn, Germany) were used to collect and process the chromatographic data.

Separations were performed on Phenomenex Luna column (5 $\mu$ C18 (2), $250 \times 4.6 \mathrm{~mm}, 100 \AA)$ and gradient elution. Solvent A was methanol: water $(65: 35, \mathrm{v} / \mathrm{v})$ and solvent B was methanol: tetrahydrofuran:50mM phosphoric acid ( $\mathrm{pH}$ adjusted to $7.51 \mathrm{with} \mathrm{NaOH}$ solution) (20:20:960, v/v).

The gradient program was linear from 40 to $50 \% \mathrm{~A}$ in $24 \mathrm{~min}$, from 50 to $100 \% \mathrm{~A}$ in $30 \mathrm{~min}$, kept 10 minutes at $100 \% \mathrm{~A}$ and return linearly to the starting condition in $6 \mathrm{~min}$. Flow rate was $1 \mathrm{~mL}^{-\mathrm{min}^{-}}$ 1 , column temperature was $25^{\circ} \mathrm{C}$ and wavelengths for FLD detector were $335 \mathrm{~nm}$ for excitation and $440 \mathrm{~nm}$ for emission. Therefore, the total analysis time per sample was 70 minutes. The method has been adapted after [34].

Sample preparation: FAAs derivatization: The standard AA mixture (or sample) and OPA solution were mixed at a ratio 1 to $1 \mathrm{v} / \mathrm{v}$, at room temperature for 1 minute, then injected into the chromatographic column. The injected volume is $10 \mu \mathrm{l}$. Amino acid standard solutions w ere prepared for calibration in the range of $10-2.5 \mu \mathrm{g} \cdot \mathrm{mL}^{-1}$.

\subsection{Antimicrobial test}

The test microorganisms used in this study were: Escherichia coli ATCC 25922 and Staphylococcus aureus ATCC 25923 from the Laboratory of Microbiology, Faculty of Biology and Geology, Babeș-Bolyai University Cluj - Napoca.

The antimicrobial capacity of Milk Serum was evaluated by diffusometric susceptibility testing [35]. Milk Serum samples, in liquid form, were applied on the beads in different volumes, and were tested, by the paper disc method applied in the wells in the solid culture medium. Petri dishes with Mueller-Hinton culture medium were inoculated with $200 \mu \mathrm{L}$ test strain with a 0.2 McFarland turbidity. After removing the excess, the boxes were incubated for 1 hour at $37^{\circ} \mathrm{C}$. Then, in each Petri dish box, in the culture medium, $6 \mathrm{~mm}$ wells were sterilely cut. In these wells were placed the sterile paper rolls (see Figure 3). On these rounds wells $30 \mu \mathrm{L}$ of Milk Serum sample (total $90 \mu \mathrm{L}$ ) were inoculated in three runs. Next, incubation was continued for 24 hours at $37^{\circ} \mathrm{C}$.

\section{Results}

\subsection{Development and validation of HPLC method of whey protein}

\subsubsection{Development of HPLC method}

For separation of WP has been used a specific column based on Core-Shell particle technology, the Aeris column (WIDEPORE, $3.6 \mu \mathrm{m}, \mathrm{XB}-\mathrm{C} 18,250 \times 4.6 \mathrm{~mm}, 200 \AA$ A) (Phenomenex). A uniform porous silica layer is grown around a solid, spherical silica core, providing effective retention and selectivity with improved resolution, speed, and recovery [36]. The pore size and shell thickness provides a maximum separation power for intact proteins or smaller peptide fragments. Core-shell particles afford great advantages in the separation of proteins and other large-molecular weight compounds [37]. The other conditions, including mobile phase composition, flow rate, column temperature and detection w avelength were tested to achieve an optimal resolution of whey proteins. The method has been improved, optimized and validated after Haque et al. 2013.

Thus, in this HPLC method for WP determination, were tested different mobile phase gradient programs based on two mobile phase A, $0.1 \%$ trifluoroacetic acid (TFA) in water and B, $0.1 \%$ TFA in $80 \% \mathrm{ACN}$. The flow rate w as tested between $0.4 \mathrm{~mL} \cdot \mathrm{min}^{-1}$ to $0.9 \mathrm{~mL} \cdot \mathrm{min}^{-1}$, and a column temperature of $35^{\circ} \mathrm{C}$ and $40{ }^{\circ} \mathrm{C}$ w as applied. Therefore, the best HPLC conditions for whey proteins analysis are: linear gradient program, from 35\% B to $80 \%$ B in 15 minutes, from $80 \%$ B to $60 \%$ B in 5 minutes, and 
from $60 \% \mathrm{~B}$ to $35 \% \mathrm{~B}$ in 5 minutes; $40{ }^{\circ} \mathrm{C}$ column temperature; the flow rate at $0.7 \mathrm{~mL} \cdot \mathrm{min}^{-1}$ and the wavelength of $214 \mathrm{~nm}$.

\subsubsection{Validation of HPLC method.}

The analytical performance of the method in order to ensure that the method is suitable for its intended use, should be satisfactory with the selectivity, linearity, sensitivity, precision, accuracy (recovery), LOD, LOQ [33].

Selectivity was evaluated by comparing the retention times of the whey proteins ( $\alpha$-La, BSA, $\beta$ $\operatorname{Lg} A, \beta$-Lg B) standards added to the solvent (w ater) and in the presence of the matrices (Milk Serum). The retention times of studied whey proteins are $9.12 \mathrm{~min}$ for BSA, 9.56 min for $\alpha-\mathrm{La}, 10.79 \mathrm{~min}$ for $\beta$-Lg A and $11.05 \mathrm{~min}$ for $\beta$-Lg B (Figure 1). The elution order shows BSA and $\alpha$-La eluted before $\beta$ lactglobulins. For $\beta$-Lg B were eluted before $\beta$-Lg A $[10,13,37]$.
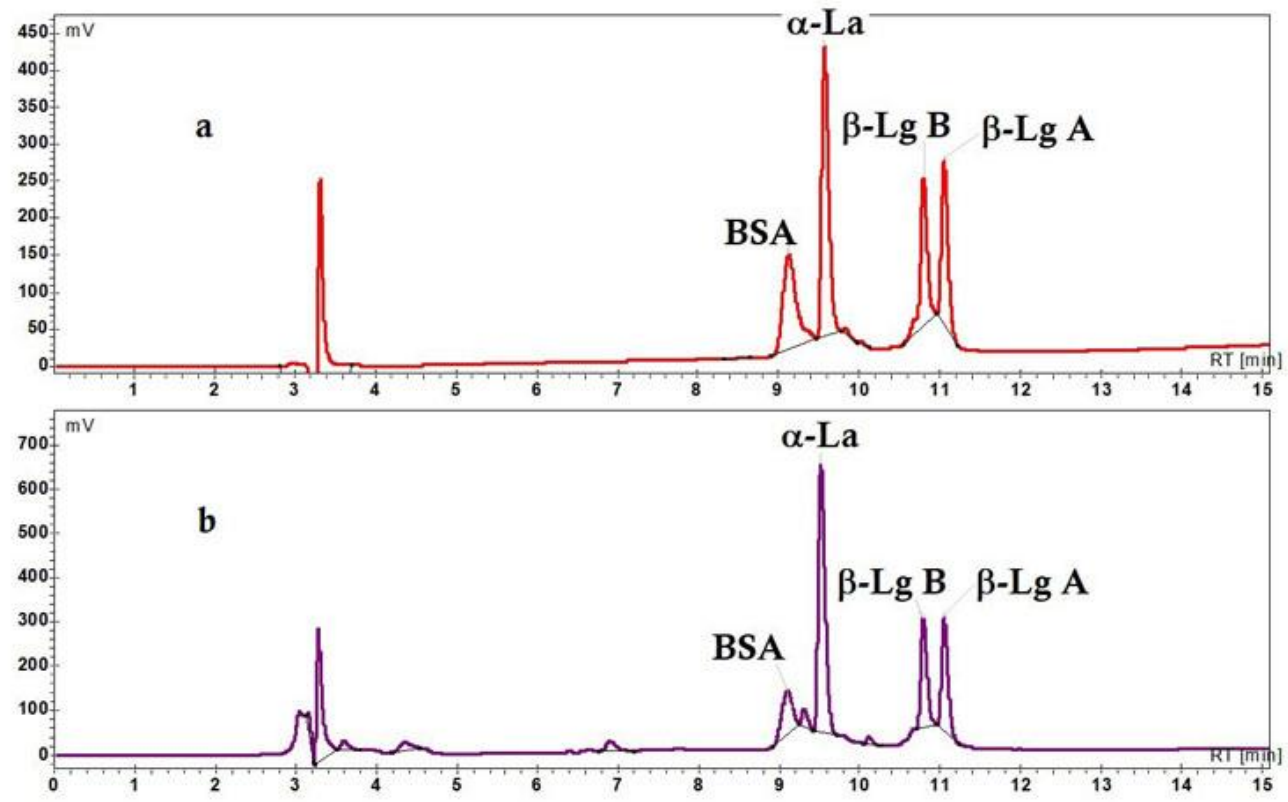

Figure 1. Chromatograms of: (a) standard solution of whey proteins (each of $150 \mu \mathrm{g} \cdot \mathrm{mL}^{-1}$ ) and (b) a mixture of Milk Serum sample with standard mixture $\left(125 \mu \mathrm{g} \cdot \mathrm{mL}^{-1}\right)(1: 1, \mathrm{v} / \mathrm{v})$.

In chromatogram of Figure $1 \mathrm{~b}$ can be observed a good separation of each studied proteins and the small peaks that are attributable to the other minor protein present in Milk Serum sample. The small peak between BSA and $\alpha$-Lactalbumin (Figure $1 \mathrm{~b}$ ) represents lactofer rin [13].

The others whey proteins present in Milk Serum sample not interfere with the studied analy tes and can be concluded that the proposed HPLC method was selective one.

These dairy drinks based on Milk Serum have similar physicochemical characteristics with the sweet whey and also the low of total protein and mineral content and a moderate quantity of lactose, which recommend them for curative and palliative purposes in medical fields such as obesity, diabetes mellitus type II or kidney diseases [38].

Linearity of the method was evaluated through the construction of four calibration curves by the external standard method at six different concentration levels ranging from 20 to $250 \mu \mathrm{g} \cdot \mathrm{mL}^{-1}$. The linear relation was estimated between peak area and injected amount of studied proteins. The limit of detection (LOD) and limit of quantitation (LOQ) were the concentrations of a compound at which its signal-to-noise ratios were detected as 3:1 and 10:1, respectively. They were determined by serial dilution of samples solution under the described HPLC-UV conditions. Parameters of calibration curves are reported in Table 1. 
Table 1. Linear regression data, LOD and LOQ of the WP.

\begin{tabular}{ccccccc}
\hline $\begin{array}{c}\text { Parameters/ } \\
\text { Whey protein }\end{array}$ & $\begin{array}{c}\mathrm{RT}^{\mathrm{a}} \\
{[\mathrm{min}]}\end{array}$ & Calibration curve ${ }^{\mathrm{b}}$ & $\begin{array}{c}\text { Regression } \\
\text { coefficient } \mathrm{c} \\
R^{2}\end{array}$ & $\begin{array}{c}\text { Linear } \\
\text { range } \\
\left(\mu \mathrm{g} \mathrm{mL}^{-1}\right)\end{array}$ & $\begin{array}{c}\text { LOD d }^{\mathrm{d}} \\
\left(\mu \mathrm{gL} \mathrm{mL}^{-1}\right)\end{array}$ & $\begin{array}{c}\text { LOQ }^{\mathrm{d}} \\
\left(\mu \mathrm{mL}^{-1}\right)\end{array}$ \\
\hline BSA & 9.12 & $\mathrm{Y}=0.19375 \mathrm{X}+4.6643$ & 0.9953 & $20-250$ & 3.2 & 10.08 \\
$\alpha$-La & 9.56 & $\mathrm{Y}=0.27911 \mathrm{X}+0.7138$ & 0.9964 & $20-250$ & 0.4 & 1.35 \\
$\beta$-Lg A & 10.79 & $\mathrm{Y}=0.13492 \mathrm{X}+0.3545$ & 0.9959 & $20-250$ & 0.83 & 2.5 \\
$\beta$-Lg B & 11.05 & $\mathrm{Y}=0.14051 \mathrm{X}+0.2056$ & 0.9988 & $20-250$ & 0.71 & 2.14 \\
\hline
\end{tabular}

a RT, the retention time; ${ }^{b} \mathrm{Y}$, the peak area and $\mathrm{X}$, the concentration of reference compound $\left(\mu \mathrm{g} \mathrm{mL}^{-1}\right)$; c $R^{2}$ regression coefficient of calibration curve ( $\mathrm{n}=6$, seven points); d LOD, the limit of detection $(\mathrm{S} / \mathrm{N}=$ 3); LOQ, thelimit of quantification $(\mathrm{S} / \mathrm{N}=10)$;

As seen there, the good regression coefficients, $R^{2}>0.99$, of calibration curves were obtained within test ranges. The LODs and LOQs were in the range of $0.4-3.2 \mu \mathrm{g} \mathrm{mL}-1$ and $1.35-10.08 \mu \mathrm{g} \mathrm{mL}$ 1 , respectively, showing the good sensitivity of the method.

Intra- and inter-day precision for each whey protein at low, intermediate and high concentration levels are listed in Table 2.

Table 2. Intra- and inter-day precision of whey proteins

\begin{tabular}{|c|c|c|c|c|c|}
\hline \multirow[b]{2}{*}{$\begin{array}{l}\text { Whey } \\
\text { protein }\end{array}$} & \multirow[b]{2}{*}{$\begin{array}{l}\text { Concentration } \\
\left(\mu g \cdot \mathrm{mL}^{-1}\right)\end{array}$} & \multicolumn{2}{|c|}{ Intra-Day Precision $(\mathrm{n}=6)$} & \multicolumn{2}{|c|}{ Inter-Day Precision $(\mathrm{n}=9)$} \\
\hline & & $\begin{array}{c}\text { Measured } \\
\text { concentration } \\
\text { Mean }{ }^{\mathrm{a}} \pm \mathrm{SD} \text {, } \\
\left(\mu \mathrm{g} \cdot \mathrm{mL}^{-1}\right)\end{array}$ & $\begin{array}{l}\text { RSD c } \\
(\%)\end{array}$ & $\begin{array}{c}\text { Measured } \\
\text { concentration } \\
\text { Mean }{ }^{\mathrm{a}} \pm \mathrm{SD} \text {, } \\
\left(\mu \mathrm{g} \cdot \mathrm{mL}^{-1}\right)\end{array}$ & $\begin{array}{l}\text { RSD c } \\
(\%)\end{array}$ \\
\hline $\mathrm{BSA}$ & 50 & $49.27 \pm 1.88$ & 3.81 & $50.34 \pm 2.08$ & 4.13 \\
\hline$\alpha-\mathrm{La}$ & 250 & $250.23 \pm 1.56$ & 0.62 & $249.18 \pm 1.16$ & 0.46 \\
\hline$\beta-\operatorname{Lg} B$ & 150 & $148.08 \pm 2.34$ & 1.58 & $148.34 \pm 2.9$ & 1.95 \\
\hline$\beta-\operatorname{Lg} A$ & 100 & $100.54 \pm 0.76$ & 0.75 & $100.98 \pm 1.07$ & 1.06 \\
\hline
\end{tabular}

${ }^{a}$ Mean $=$ Average of $\mathrm{n}$ determination; ${ }^{\mathrm{b}} \mathrm{SD}=$ Standard deviation; ${ }^{\mathrm{c}} \mathrm{RSD}=$ Relative standard deviation .

The intra-day precision (\% RSD) varied from 0.62 to $3.81 \%$ while the inter-day precision ranged varied from 0.46 to $4.13 \%$. Results indicate that the method for quantification of whey protein is precise conform [33].

The accuracy of the quantitative analysis method was evaluated by measuring recovery (Table 3) through standard addition method. It w as evaluated from Low level $\left(50 \mu \mathrm{g} \cdot \mathrm{mL}^{-1}\right)$, at Intermediate level $\left(150 \mu \mathrm{g} \cdot \mathrm{mL}^{-1}\right)$ and to high level $\left(200 \mu \mathrm{g} \cdot \mathrm{mL}^{-1}\right)$.

Table 3. Recovery tests by HPLC method of the whey proteins from Milk Serum sample.

\begin{tabular}{|c|c|c|c|c|c|c|}
\hline \multirow{2}{*}{$\begin{array}{l}\text { Whey } \\
\text { protein }\end{array}$} & \multicolumn{2}{|c|}{ Low level (\%) } & \multicolumn{2}{|c|}{ Intermediatelevel (\%) } & \multicolumn{2}{|c|}{ High level (\%) } \\
\hline & Mean ${ }^{a} \pm S D b$ & $\mathrm{RSD}^{\mathrm{c}}$ & Mean ${ }^{a} \pm S D b$ & RSD c & Mean ${ }^{a} \pm S D b$ & $\mathrm{RSD}^{\mathrm{c}}$ \\
\hline BSA & $100.68 \pm 1.82$ & 1.80 & $102.4 \pm 1.98$ & 1.95 & $98.18 \pm 2.46$ & 2.5 \\
\hline$\alpha-\mathrm{La}$ & $103.07 \pm 0.38$ & 0.37 & $100.98 \pm 1.75$ & 1.73 & $99.67 \pm 1.58$ & 1.59 \\
\hline$\beta-\operatorname{Lg} B$ & $98.31 \pm 2.51$ & 2.55 & $99.97 \pm 2.75$ & 2.75 & $99.37 \pm 2.98$ & 2.99 \\
\hline$\beta-\operatorname{Lg} A$ & $96.79 \pm 4.23$ & 4.37 & $97.53 \pm 4.75$ & 4.87 & $98.88 \pm 3.18$ & 3.22 \\
\hline
\end{tabular}

a Mean = Average of $\mathrm{n}$ determination; ${ }^{\mathrm{b}} \mathrm{SD}=$ Standard deviation; ${ }^{\mathrm{c}} \mathrm{RSD}=$ Relative standard deviation. Low level, $50 \mu \mathrm{g} \cdot \mathrm{mL}^{-1}$; Intermediatelevel, $150 \mu \mathrm{g} \cdot \mathrm{mL}^{-1}$; High level, $200 \mu \mathrm{g} \cdot \mathrm{mL}^{-1}$;

The obtained recoveries of WP of Milk Serum sample were from 96.79 to $103.07 \%$. Similar results for RSD values of precision and \% recoveries of whey proteins were obtained by $[9,15,39]$. 


\subsection{HPLC determination of whey proteins in Milk Serum dairy drinks}

The developed and validated HPLC method for determination of WP was applied to analysis of different types of dairy drinks based on Milk Serum: six samples (Z-1 to Z-6) is based on milk serum obtained from different batches of cow milk, three samples is dairy drinks of Milk Serum with content of ginger, cacao, honey and colloidal silver, and one sample is dairy drink for baby children.

The quantities of whey proteins, $\alpha-\operatorname{La}, B S A, \beta-\operatorname{Lg} A$ and $\beta-\operatorname{Lg} B$, in these dairy drinks are considered valuablebioactive components (Figure 2).

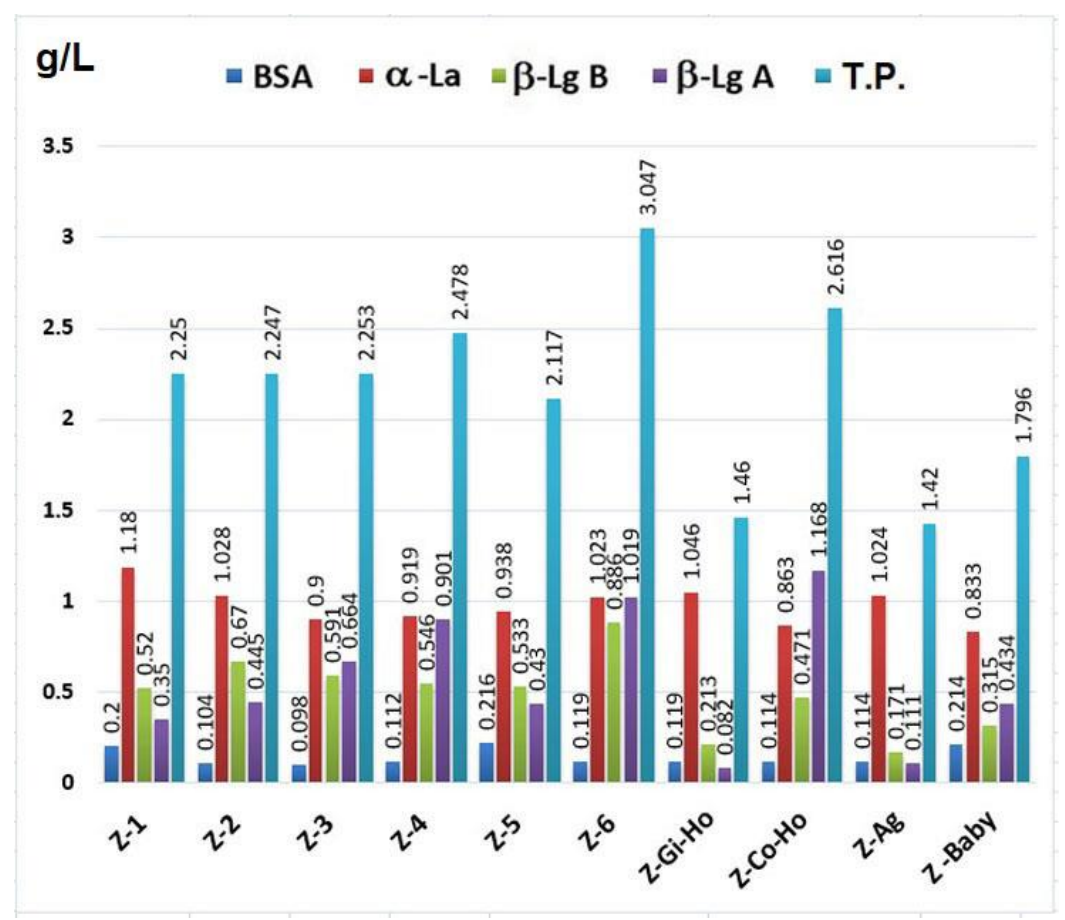

Figure 2. The concentrations of whey proteins (BSA, $\alpha-\operatorname{La}, \beta-\operatorname{Lg} B, \beta-\operatorname{Lg} A)$ and studied total proteins (T.P.) in dairy drinks based on Milk Serum.

The results show that the $\alpha$-La is major whey protein in all these drinks less Z-Gi-Ho sample, with amounts between 1.18 and $0.833 \mathrm{~g} \cdot \mathrm{L}-1$. The $\beta$ - $\mathrm{Lg} B$ whey protein were found amounts betw een 0.67 and $0.171 \mathrm{~g} \cdot \mathrm{L}-1$ for Z-1, Z-2 and Z-5, Z-Gi-Ho, and Z-Ag samples. For samples Z-3, Z-4, Z-6, ZCo-Ho and Z-Baby, the $\beta$-Lg A was found in a larger quantity with values between 0.434 and 1.168 $\mathrm{g} \cdot \mathrm{L}-1$. The total studied WP in dairy drinks varied between 1.42 and $3.047 \mathrm{~g} \cdot \mathrm{L}^{-1}$.

The composition and characteristics of whey are dependent on the milk source (cow, sheep, etc.), the feed of the milk-producing animal, the processing method used, the time of the year, and the stage of lactation [7].

\subsection{HPLC profile of FAAs in Milk Serum sample}

The chromatographic FAAs profile was determined from lyophilized samples of Milk Serum. The content of FAAs is found in small quantities in these dairy drinks, due to the fact that the concentration of some free essential amino acids may decrease during whey processing [41].

In Figure 3 are presented the chromatograms of amino acids standard mixture and the Milk Serum sample. 


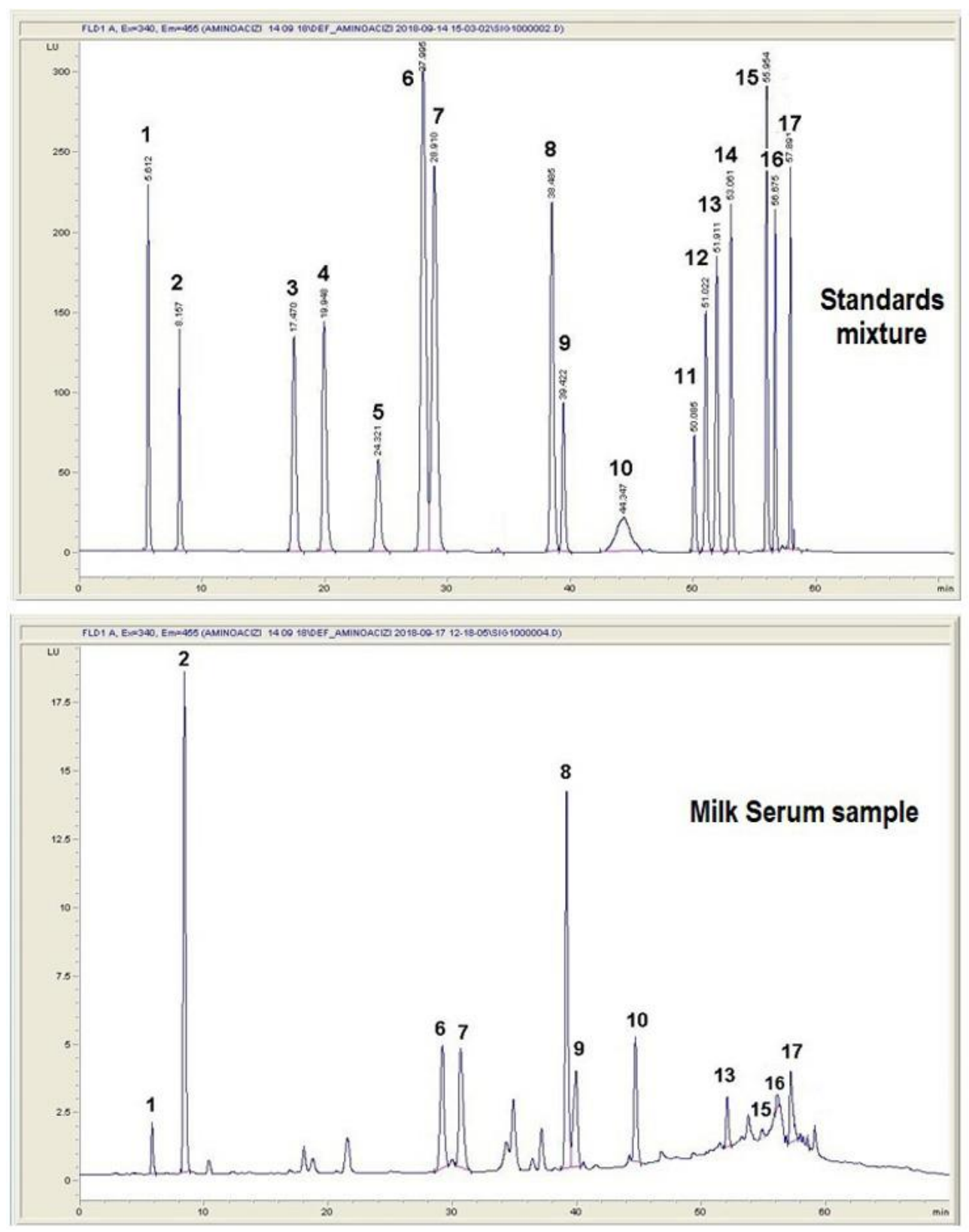

Figure 3. HPLC-FLD chromatograms of the standard amino acid mixture of $10 \mu \mathrm{g} \cdot \mathrm{mL}^{-1}$ and Milk Serum sample. FAAs: aspartic acid (1), glutamic acid (2), serine (3), histidine (4), arginine (5), glycine (6), threonine (7), alanine (8), tyrosine (9), cysteine (10), tryptophan (11), methionine (12), valine (13), phenylalanine(14), isoleucine (15), leucine (16), lysine (17).

Whey proteins contain essential and non-essential amino acids in higher concentration as compared to protein from vegetable sources [42]. The whey proteins from supplements have been recognized for their high nutritional quality, fast absorption, and as a rich source of essential amino acids, mainly branched-chain amino acids, such as leucine, isoleucine, and valine [2,41].

Figure 4 show s the amounts of free amino acids, $\left(\mathrm{mg} \cdot \mathrm{g}^{-1}\right)$ of the lyophilized Milk Serum samples. 


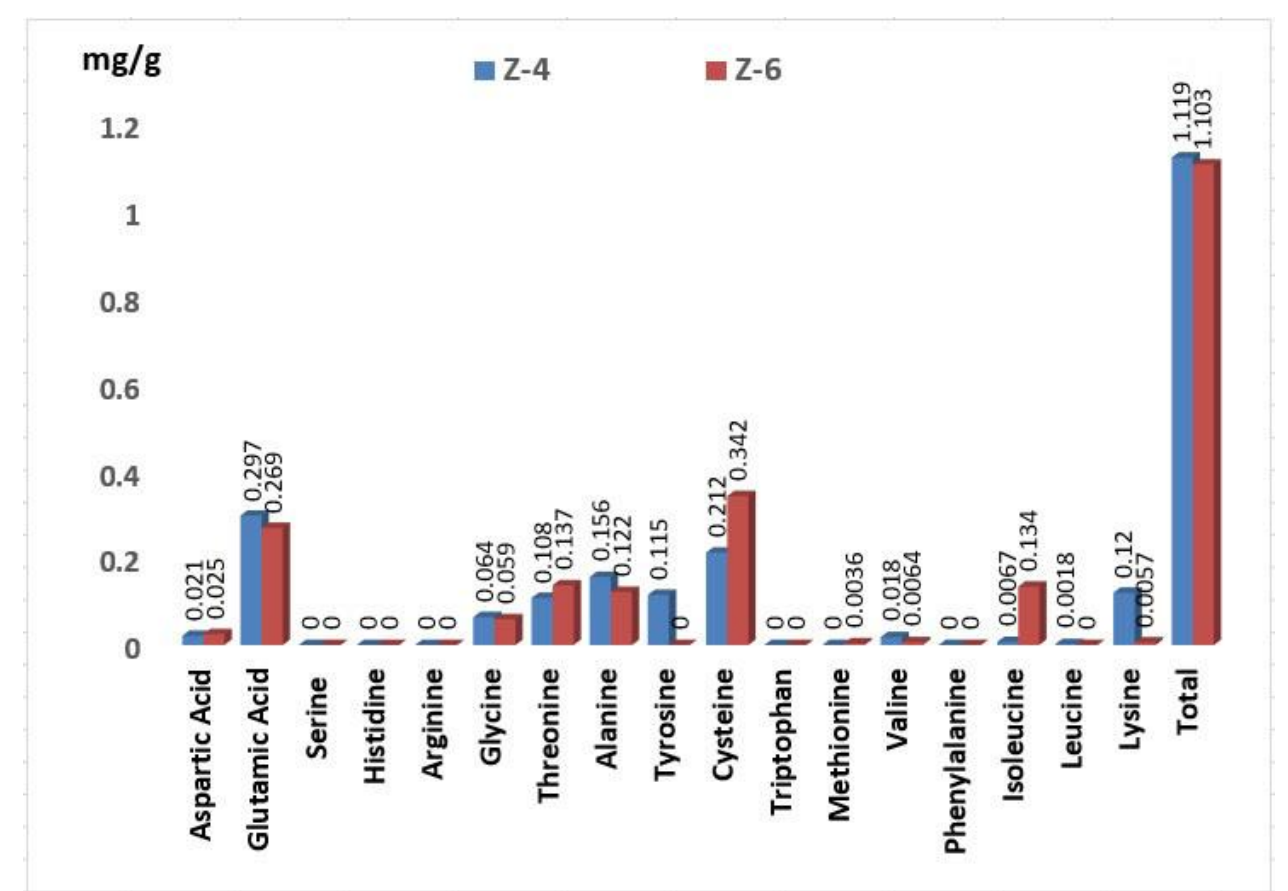

Figure 4. The amounts $\left(\mathrm{mg}^{-1} \mathrm{~g}^{-1}\right.$ ) of free amino acids (FAAs) in thelyophilized Milk Serum samples.

The composition of milk serum samples regarding free essential amino acids shows that isoleucine $0.134 \mathrm{mg} \cdot \mathrm{g}^{-1}(\mathrm{Z}-6)$ and lysine $0.12 \mathrm{mg} \cdot \mathrm{g}^{-1}(\mathrm{Z}-4)$ followed by threonine $0.108 \mathrm{mg} \cdot \mathrm{g}^{-1}(\mathrm{Z}-4)$ and $0.137 \mathrm{mg} \cdot \mathrm{g}^{-1}(\mathrm{Z}-6)$ represent the major components. Leucine $w$ as present only in a small concentration $0.0018 \mathrm{mg} \cdot \mathrm{g}^{-1}$ in Z-4. However the presence of other free essential amino acids like histidine, methionine, phenylalanine and tryptophan are not shown in Z-4.

On the other hand the presence of free non-essential amino acids present in a large concentration were the glutamic acid with $0.297 \mathrm{mg} \cdot \mathrm{g}^{-1}(\mathrm{Z}-4)$ and $0.269(\mathrm{Z}-6) \mathrm{mg} \cdot \mathrm{g}^{-1}$ followed by alanine with 0.156 $\mathrm{mg} \cdot \mathrm{g}^{-1}(\mathrm{Z}-4)$ and $0.122 \mathrm{mg} \cdot \mathrm{g}^{-1}(\mathrm{Z}-6)$, cysteine $0.121 \mathrm{mg} \cdot \mathrm{g}^{-1}(\mathrm{Z}-4)$ and $0.342 \mathrm{mg} \cdot \mathrm{g}^{-1}(\mathrm{Z}-6)$ and tyrosine $0.115 \mathrm{mg} \cdot \mathrm{g}^{-1}(\mathrm{Z}-4)$.

Also, the glycine with $0.064 \mathrm{mg} \cdot \mathrm{g}^{-1}(\mathrm{Z}-4)$ and $0.059 \mathrm{mg} \cdot \mathrm{g}^{-1}(\mathrm{Z}-6)$ and aspartic acid $0.021 \mathrm{mg} \cdot \mathrm{g}^{-1}(\mathrm{Z}-$ 4) and $0.025 \mathrm{mg} \cdot \mathrm{g}^{-1}(Z-6)$ were present in both Milk Serum samples. Valine exhibit in both samples small concentrations $0.018 \mathrm{mg} \cdot \mathrm{g}^{-1}(\mathrm{Z}-4)$ and $0.0064 \mathrm{mg} \cdot \mathrm{g}^{-1}(\mathrm{Z}-6)$.

The content of free amino acids it was analyzed from lyophilized samples of Milk Serum. The content of free amino acids is found in small quantities in these dairy drinks, due to the fact that the concentration of some free essential amino acids may decrease during whey processing [41]. However, the our data obtained on free amino acid abundance in Milk Serum lyophilized samples were consistent with the results obtained by A. Yasmin et al., 2013.

\subsection{Antimicrobial study}

Antimicrobial activity of Milk Serum sample as the base of the others studied investigated dairy drinks was studied conform to 2.3 section. It was observed that after 24 hours of incubation, for both Gram-positive (S. aureus) and gram-negative (E. coli) strains had appeared the diameters of the inhibition zones $(\mathrm{mm})$ presented in Figure 5.

Interpretation was performed by measuring the diameter of the zone of bacterial inhibition (of halo formed around the tested material) by two perpendicular lines with a millimeter ruler with a precision of $0.5 \mathrm{~mm}$ after 24 hours. Each testing was performed three times. 

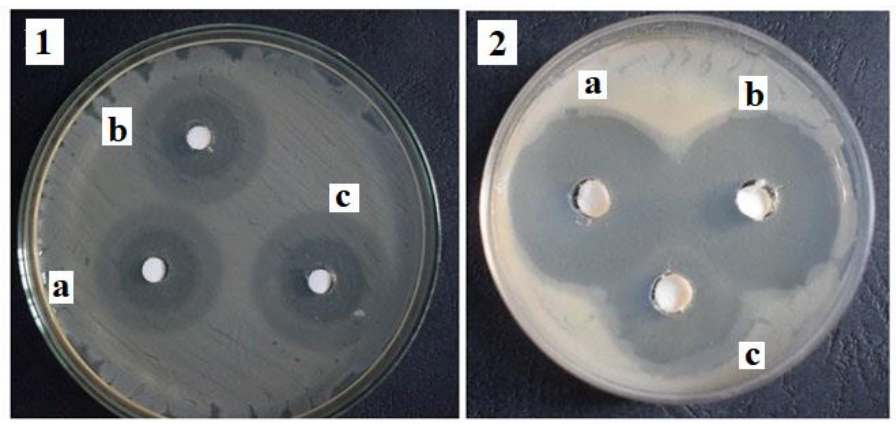

\begin{tabular}{|c|c|c|}
\hline \multirow{2}{*}{$\begin{array}{l}\text { Milk } \\
\text { Serum }\end{array}$} & \multicolumn{2}{|c|}{$\begin{array}{r}\text { Diameter of inhibition zone } \\
(\mathrm{mm})\end{array}$} \\
\cline { 2 - 3 } sample & $\begin{array}{r}\text { Staphylococcus } \\
\text { aureus }(1)\end{array}$ & $\begin{array}{r}\text { Escherichia } \\
\text { coli (2) }\end{array}$ \\
\hline a & 12 & 25 \\
\hline b & 12 & 25 \\
\hline c & 12 & 20 \\
\hline
\end{tabular}

Figure 5. Inhibition of microbial grow th in Milk Serum sample (Z-4) against tw o bacterial strains S. aureus (1) and E. coli (2).

From Figure 5(1) it can be observed after 24 hours, for all three samples, a diameter of the inhibition zone of $12 \mathrm{~mm}$ against S. aureus. In the case of the first two samples of Figure 5(2) $(a, b)$, the antibacterial effect is visibly higher against $E$. coli than against S. aureus; the diameter of the inhibition zone recorded after 24 hours being $25 \mathrm{~mm}$. In the case of Figure 3(2), sample c, a diameter of the inhibition zone against e-coli was recorded with somewhat low er, $20 \mathrm{~mm}$ but also in this case, higher than against $S$. aureus. Based on the diameter of inhibition zone, the bacterial killing ability of Milk Serum is $12 \mathrm{~mm}$ for S. aureus and $25 \mathrm{~mm}$ for E. coli.

Antimicrobial activity of Milk Serum sample as the base of studied dairy drinks was investigated, and associated with presence of whey proteins, $\alpha$-lactalbumin, $\beta$-lactoglobulin, bovine serum albumin and other minor proteins [47].

\section{Discussion}

Development of HPLC method of whey protein ( $\alpha$-La, BSA, $\beta$ - $\operatorname{Lg} A, \beta-\mathrm{Lg}$ B) involved separation on a specific column based on Core-Shell particle technology, with great advantages in the separation of proteins and other large-molecular weight compounds [36,37]. The HPLC method has been improved, optimized and validated after Haque et al. 2013, by testing different mobile phase composition, flow rate, column temperature and detection wavelength in order to achieve an optimal resolution of studied whey proteins.

The method validation parameters, the selectivity, linearity, sensitivity, precision, accuracy (recovery), LOD, LOQ, were evaluated conform ICH guideline [33] to good values.

In chromatogram of Figure $1 \mathrm{~b}$ can be observed a good separation of each studied proteins and the small peaks that are attributable to the other minor protein present in Milk Serum sample, like the small peak between BSA and $\alpha$-La that represents lactoferrin [13]. The obtained recoveries of WP of Milk Serum sample were from 96.79 to $103.07 \%$. Similar results for RSD values of precision and \% recoveries of whey proteins were obtained by other authors $[9,15,39]$. Thus, can be concluded that the proposed HPLC method was selective one and can be used in laboratory for routine analysis.

The total studied WP in dairy drinks varied between 1.42 and $3.047 \mathrm{~g} \cdot \mathrm{L}^{-1}$, the composition and characteristics of whey are dependent on the milk source (cow, sheep, etc.), the feed of the milkproducing animal, the processing method used, the time of the year, and the stage of lactation [7].

The whey proteins are the valuable constituents of sweet whey and stand out for their high nutritional value in terms of biological value and composition in essential amino acids. $\alpha$-La is a primary protein found in human breast milk and together with $\beta$-Lg are a source of essential and branched chain amino acids. Besides, the BSA is also a source of essential am ino acids [2].

Different bioactivities have been associated to these proteins, among them antihypertensive, antimicrobial, opioid, antioxidant and immunomodulant activity being the most studied. The $\beta$ - $\mathrm{Lg}$ protein has the role in resistant carrier of retinol (a provitamin A) and participate in the digestion of milk lipids during the neonatal period and, more this protein may play a role in the absorption and subsequent metabolism of fatty acids [40]. 
The chromatographic FAAs profile was determined from lyophilized samples of Milk Serum and its obtained values are due to because the content of FAAs decrease during whey processing [41].

However, the our data obtained on free amino acid abundance in Milk Serum liophilized samples were consistent with the results obtained by A. Yasmin et al., 2013.

Whey is a residual product of the milk industry with various therapeutic properties, is rich in protein residues, oligopeptides, amino acids but especially lactose [43,44]. Thus, whey proteins could be considered as an abundant resource to obtain antimicrobial peptides. Beside whey proteins, lactoferrin, lysozyme, and their proteolytic fragments, the antimicrobial potential of peptides encrypted within the $\beta$-Lg and $\alpha$-La sequences are becoming increasingly studied. Bioactive peptides derived from whey proteins have been also associated with immunomodulatory, anticancer, opioid and hypocholesterolemic activities [1,45].

Antimicrobial activity of Milk Serum sample as the base of studied dairy drinks was investigated, and associated with presence of whey proteins, $\alpha$-lactalbumin, $\beta$-lactoglobulin, bovine serum albumin and other minor proteins [46]. The milk whey is rich in protein residues, oligopeptides, amino acids but especially lactose [44,46], thus could be considered as an abundant resource to obtain antimicrobial peptides. Antimicrobial and antiviral actions, immune system stimulation, anticarcinogenic activity and other metabolic features have indeed been associated $w$ ith such whey proteins, $\alpha$-lactalbumin, $\beta$-lactoglobulin, lactoferrin, lactoperoxidase, and bovine serum albumin [47].

\section{Conclusions}

In this study, a simple and efficient RP-HPLC method were successfully validated and applied for determination of WP, $\alpha-\operatorname{La}, B S A, \beta-\operatorname{Lg} A$ and $\beta-\operatorname{Lg} B$, in the some dairy drinks based on Milk Serum providing satisfactory accuracy with low limits of detection. The total studied WP in dairy

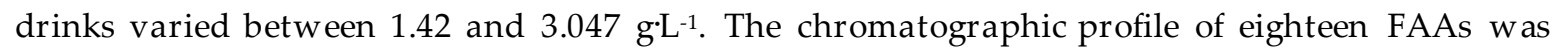
determined in lyophilized Milk Serum samples by RP-HPLC method with amounts between 1.1037 and $1.1195 \mathrm{mg}^{-1}$. The obtained results confirm that studied dairy drinks based on the Milk Serum constitutes a valuable sources of bioactive components which recommend them for human healthy nutrition, as well as for curative and palliative purposes in medical fields such as obesity, diabetes mellitus ty pe II or kidney diseases.

\section{Supplementary Materials: -}

Author Contributions: Conceptualization, D.P., M.F. and M.V.; methodology, M.F., M.V., R.C. and A.S.P.; software, MF; validation, M.F.; formal analysis, R.C. and D.P.; investigation, M.F. , M.V. and R.C.; resources, M.M.; data curation, D.P..; writing - original draft preparation, M.F.; writing - review and editing, M.F. and M.M.; visualization, M.M.; supervision, M.M and V.T.; project administration, M.M.; funding acquisition, M.M. All authors have read and agreed to the published version of the manuscript.

Funding: This work was financially supported by the Romanian Programme for Research, Development and Innovation PNCDI III, Cod: PN-III-P2-2.1-BG-2016-0335, Contract no 28BG/2016, http://www.usamvcluj.ro/profi-zonar/.

Acknowledgments: The authors thank to S.C. EmbryOm Capital investment S.R.L., Satu-Mare, Romania for providing the samples of dairy drinks.

Conflicts of Interest: The authors decla re no conflict of interest.

\section{References}

1. Chatterton D.E.W., Smithers G., Roupas P., Brodkorb A. Bioactivity of $\beta$-lactoglobulin and $\alpha$-lactalbumin Technological implications for processing. Int. Dairy J. 2006, 16, 1229-1240. https://doi.org/10.1016/j.idairyj.2006.06.001.

2. Marshall K. Therapeutic Applications of Whey Protein. Altern. Med. Rev. 2004, 9, 136-156. 
3. Schad G., Bollig B. The Application Notebook, 2015, http://www.chromatographyonline.com/fast-andsimple-determination-free-amino-acids-milk.

4. Brandelli, A., Daroit, D.J., Folmer Corrêa, A.P. Whey as a source of peptides with remarkable biological activities. Food Res. Int. 2015, 73, 149-161. https://doi.org/10.1016/j.foodres.2015.01.016.

5. Sturaro, A., de Marchi, M., Masi, A., Cassandro, M. Quantification of whey proteins by reversed phaseHPLC and effectiveness of mid-infrared spectros copy for their ra pid pre diction in sweet whey. J. Dairy Sci., 2016, 99, 68-76. https://doi.org/10.3168/jds.2014-9077.

6. Santos M.J., Teixeira J.A., Rodrigues L.R. Fractionation of the major whey proteins and isolation of $\beta$ Lactoglobulin variants by anion exchange chromatography. Sep. Purif. Technol. 2012, 90, 133-139. https://doi.org/10.1016/j.seppur.2012.02.030.

7. Ganju S., Gogate P.R. A review on a pproaches for efficient re covery of whey proteins from dairy industry effluents. J. Food Eng. 2017, 215, 84-96. https://doi.org/10.1016/j.jfoodeng.2017.07.021.

8. Bonfatti V., Grigoletto L., Cecchinato A., Gallo L., Carnier P. Validation of a new reversed-phase highperformance liquid chromatography method for separation and quantification of bovine milk protein genetic variants. J. Chromatogr. A 2008, 1195, 101-106. https://doi.org/10.1016/j.chroma.2008.04.075.

9. Ding X., Yang Y., Zhao S., Li Y., Wang Z. Analysis of $\alpha$-lactalbumin, $\beta$-lactoglobulin A and B in whey protein powder, colostrum, raw milk, and infant formula by CE and LC. Dairy Sci. Technol. 2011, 91, $213-$ 25. https://doi.org/10.1007/s13594-011-0006-9.

10. Rotkāja O., Goluško J., Mekšs P. Reversed-Phase High-Performance Liquid Chromatography Analysis of $\beta$-Lactoglobulin and $\alpha$-Lactalbumin in Different Types of Milk. Mat. Sci. Appl. Chem. 2016, 33, 36-39. https://doi.org/10.1515/msac-2016-0007.

11. Ren Y., Han Z., Chu X., Zhang J., CaiZ., Wu Y. Simultaneous determination of bovine $\alpha$-lactalbumin and $\beta$-lactoglobulin in infant formula by ultra-high-performance liquid chroma tography-mass, spectrometry. Anal. Chim. Acta 2010667, 96-102. https://doi.org/10.1016/j.aca.2010.04.015

12. Zhang J., Lai S., Zhang Y., Huang B., Li D., Ren Y., Multiple reaction monitoring-based determination of bovine -lactalbumin in infant formulas and whey protein concentrates by ultra-high performance liquid chromatography-tandem mass spectrometry using tryptic signature peptides and synthetic peptide standards. Anal. Chim. Acta 2012, 727, 47-53. https://doi.org/10.1016/j.idairyj.2015.05.006.

13. Boitz L.I, Fiechter G., Seifried R.K, Mayer H.K. A novel ultra-high performance liquid chromatography method for the rapid determination of $\beta$-lactoglobulin as heat load indicator in commercial milk samples. J. Chromatogr. A 2015, 1386, 98-102. https://doi.org/10.1016/j.chroma.2015.01.081

14. Czerwenka C., Maier I., Potocnik N., Pittner F., Lindner W. Absolute Quantitation of $\beta$-Lactoglobulin by protein liquid chromatography-mass spectrometry and its application to different milk products. Anal. Chem. 2007, 79, 5165-5172. https://doi.org/10.1021/ac062367d.

15. Chen Q., Zhang J., Ke X., LaiS., Li D., Yang J., Mo W., Ren Y. Simultane ous quantification of $\alpha$-lactalbumin and $\beta$-casein in human milk using ultra-performance liquid chromatography with tandem mass spectrometry based on their signature peptides and winged isotope internal standards. Biochim. Biophys. Acta 2016, 1864, 1122-1127. https://doi.org/10.1016/j.bbapap.2016.06.006.

16. Aslam M., Jiménez-Flores R., Kim H.Y., Hurley W.L. Two-dimensionale lectrophoretic analysis of proteins of bovine mammary gland secretions collected during the dry period. J. Dairy Sci. 1994, 77, 1529-1530. https://doi.org/10.3168/jds.S0022-0302(94)77093-4.

17. Wu R., Wang Z., Zhao W., Yeung W.S.B, Fung Y.S. Multi-dimension microchip-capillary electrophoresis device for de termination of functional proteins in infant milk formula, J. Chromatogr. A 2013, 1304, 220-226. https://doi.org/10.1016/j.chroma.2013.06.073.

18. Puerta A., Diez-Masa J.C, de Frutos M. Development of an immunochromatographic method to de termine $\beta$-lactoglobulin at trace le vels. Anal. Chim. Acta 2005, 537, 69-80. https://doi.org/10.1016/j.idairyj.2005.05.006.

19. Puerta A., Diez-Masa J.C, de Frutos M. Immunochromatographic de termination of $\beta$-lactoglobulin and its antigenic peptides in hypoallergenic formulas. Int. Dairy J. 2006, 16, 406-414. https://doi.org/10.1016/j.idairyj.2005.05.006.

20. de Luis R., Lavilla M., Sánchez L., Calvo M., Pérez M.D. Development and evalua tion of two ELISA formats for the detection of $\beta$-lactoglobulin in model processed and commercial foods. Food Control. 2009, 20, 643647. https://doi.org/10.1016/j.foodcont.2008.09.017. 
21. Pelaez-Lorenzo C., Diez-Masa J.C., Va sallo I., de Frutos M. Development of an optimized ELISA and a sample preparation me thod for the de tection of $\beta$-Lactoglobulin traces in baby foods. J. Agric. Food Chem. 2010, 58, 1664-1671. https://doi.org/10.1021/jf9041485.

22. Li Z., Wen F., Li Z., Zheng N., Jiang J., Xu D. Simultaneous detection of $\alpha$-Lactoalbumin, $\beta$-Lactoglobulin and Lactofe rrin in milk by Visualized Microarray. BMC Biotechnol. 2017, 17, 2-9. DOI: 10.1186/s12896-0170387-9.

23. Henderson, J.W., Ricker, R.D., Cliff, W.I. Rapid, accurate, sensitive and reproducible HPLC analysis of amino acids. AAA Technical note 5980-1193E. USA: Agilent. 2000. https://www.agilent.com/cs/library/chromatograms/59801193.pdf

24. Fonseca B.M, Cristóvão A.C, Alves G. An easy-to-use liquid chromatography method with fluore scence detection for the simultaneous determination of five neuroactive a mino acids in different regions of rat brain. J Pharmacol. Toxicol. Methods, 2018, 91, 72-79. https://doi.org/10.1016/j.vascn.2018.02.002.

25. Liyanaarachchia G.V.V., Mahanama K.R.R., Somasiri H.P.P.S., Punyasiri P.A.N. Development and validation of a method for direct, underivatized analysis of free amino acids in rice using liquidchromatography-tandem mass spectrometry. J. Chromatogr. A 2018, 1568, 131-139. https://doi.org/10.1016/j.chroma.2018.07.035.

26. Ozcan S., Senyuva H.Z. Improved and simplified liquid chromatography / a tmospheric pre ssure chemical ioniza tion mass spectrometry method for the a nalysis of underivatize d free a mino a cids invarious foods. J. Chromatogr. A 2006, 1135, 179-185. https://doi.org/10.1016/j.chroma.2006.09.039.

27. Kaspar H., Dettmer K., Gronwald W. Oefner, P.J. Automated GC-MS analysis of free amino acids in biological fluids. J. Chromatogr. B 2008, 870, 222-232. https://doi.org/10.1016/j.jchromb.2008.06.018.

28. Omar, M.M.A., Elbashir, A.A., Schmitz, O.J. Capillary electrophoresis method with UV-detection for analysis of free amino acids concentrations in food, Food Chem. 2017, 214, 300-307. https://doi.org/10.1016/j.foodchem.2016.07.060.

29. Hogenboom, J.A., Incecco1, P.D., Fuselli, F., Pellegrino, L. Ion-exchange chromatographic method for the determination of the free a mino acid composition of cheese and other dairy products: an inter-laboratory validation study. Food Anal. Methods 2017, 103, 137-3148. DOI 10.1007/s12161-017-0876-4.

30. Jajić I., Krstovic S., Glamocic D., Jaksic S., Abramovic B. Validation of an HPLC method for the determination of amino acids in feed. J. Serb. Chem. Soc. 2013, 78, 839-850. UDC 547.466+543.544.5.068.7:641.3.002.2.

31. Kamara J.S., KonishiS., Sa sanuma T., Abe T. Variation in free amino acid profile among some rice (Oryza sativa L.) cultivars. Breeding Sci. 2010, 60, 46-54. https://doi.org/10.1270/jsbbs.60.46.

32. Mey, E.D., Markiewicz, G.D., Maere, H.D., Peeters, M.C., Derdelinckx, G., Paelinck, H., Kowalska, T. Dabsyl derivatisation as an alternative for dansylation in the detection of biogenic amines in fermented meat products by reversed phase high performance liquid chromatography. Food Chem. 2012, 130, 10171023. ttps://doi.org/10.1016/j.foodchem.2011.07.124.

33. ICH harmonised tripartite guideline. Validation of analytical procedures: Text and methodology Q2(R1). 2005, pp. 1-17. http://www.ich.org/fileadmin/Public_Web_Site/ICH_Products/Guidelines/Quality/Q2_R1/ Step4/Q2_R1_Guideline.pdf.

34. https://www.sigmaaldrich.com/content/dam/sigma-aldrich/docs/Sigma-Aldrich/Datasheet/p0532dat.pdf.

35. Carpa R., Dragan-Bularda M., Muntean V. General Microbiology-Practical Work, Publisher: Presa Unive rsitara Cluj, Cluj-Na poca, 2014, pp. ?????

36. González-Ruiz V., Olives A.I., Martín M.A. Core-shell particles lead the way to renewing high-performance liquid chromatography. Trends Anal. Chem. 2015, 64, 17-28. https://doi.org/10.1016/j.trac.2014.08.008.

37. Haque M.A, Aldred P., Chen J., Barrow C.J., Adhikari B. Comparative study of denaturation of whey protein isolate (WPI) in convective air drying and isothermal heat treatment processes. Food Chem. 2013, 141, 702-71. https://doi.org/10.1016/j.foodchem.2013.03.035.

38. Prodan D., Filip M., Moldovan M., Perhaița I., Scurtu F., Silaghi Dumitrescu L., Dreanca A., Marcus I. Physicochemical cha racteriza tion of some new dairy beverages based on lactoserum, J. Environ. Prot. Ecol. 2018, 19, 686-693.

39. Al-Rimawi F. Development and Validation of HPLC-UV Method for Determination of Bovine Serum Albumin and Myoglobin Proteins. Int. Res. J. Pure $\mathcal{E}$ Appl. Chem. 2014, 4, 585-593. https://doi.org/10.9734/IRJPAC/2014/9391. 
40. Hernández-Ledesma B., Ramos M., Gómez-Ruiz J.A. Bioactive components of ovine and caprine cheese whey. Small Rumin. Res. 2011, 101, 196-204. https://doi.org/10.1016/j.smallrumres.2011.09.040.

41. Almeida C.C., Conte-Júnior C.A., Silva A.C.O., Alvares T.S. Whey protein: Composition and functional properties. Encicl. Bio. 2013, 9, 1840-1854.

42. Yasmin A., Butt M. S., Sameen A., Shahid M. Physicochemical and Amino Acid Profiling of Chee se Whey. Pak. J. Nutr. 2013, 12, 455-459. https://doi.org/10.3923/pjn.2013.455.459.

43. Farnaud S., Evans R.W. Lactoferrin-a multifunctional protein with antimicrobial properties. Mol. Immunol. 2003, 40, 95-405. https://doi.org/10.1016/S0161-5890(03)00152-4.

44. Tomita M., Wakabayashi H., Yamauchi K., Teraguchi S., Haya sawa H. Bovine lactoferrin and lactoferricin derived from milk: production and applications. Biochem. Cell. Biol. 2002, 80, 109-112. https://doi.org/10.1139/o01-230.

45. Hernández-Ledesma B., García-Nebot M.J., Fernández-Tomé S., Amigo L., Recio I.,. Dairy protein hydrolysates: Peptides for health benefits. Int. Dairy J. 2014, 38, 82-100. https://doi.org/10.1016/j.idairyj.2013.11.004.

46. Farnaud S., Evans R.W.,. Lactoferrin-a multifunctional protein with antimicrobial properties. Mol. Immunol. 2003, 40, 95-405. https://doi.org/10.1016/S0161-5890(03)00152-4.

47. Madureira A.R., Pereira C.I., Gomes A.M.P., Pintado M.E., Malcata F.X. Bovine whey proteins - Overview on their main biological properties. Food Res. Int. 2007, 40, 1197-1211. https://doi.org/10.1016/j.foodres.2007.07.005. 